\title{
The natural furanone (5Z)-4-bromo-5- (bromomethylene)-3-butyl-2(5H)-furanone disrupts quorum sensing-regulated gene expression in Vibrio harveyi by decreasing the DNA-binding activity of the transcriptional regulator protein lux $R$
}

\author{
Tom Defoirdt, ${ }^{1,2}$ Carol M. Miyamoto, ${ }^{3}$ \\ Thomas K. Wood ${ }^{4}$ Edward A. Meighen, ${ }^{3}$ \\ Patrick Sorgeloos, ${ }^{2}$ Willy Verstraete ${ }^{1 \star}$ and \\ Peter Bossier ${ }^{2}$ \\ ${ }^{1}$ Laboratory of Microbial Ecology and Technology \\ (LabMET), Ghent University, Coupure Links 653, 9000 \\ Ghent. Belgium \\ ${ }^{2}$ Laboratory of Aquaculture and Artemia Reference \\ Center, Ghent University, Rozier 44, 9000 Ghent \\ Belgium. \\ ${ }^{3}$ Department of Biochemistry, McGill University, Mclntyre \\ Medical Sciences Building, Room 818, 3655 \\ Promenade Sir William Osler, Montreal, Canada \\ H3G $1 Y 6$. \\ ${ }^{4}$ Artie MCFerrin Department of Chemical Engineering. \\ Texas A and M University, 3122 TAMU, College Station, \\ TX 77843-3122, USA.
}

\section{Summary}

This study aimed at getting a deeper insight in the molecular mechanism by which the natural furanone (5Z)-4-bromo-5-(bromomethylene)-3-butyl-2(5H)furanone disrupts quorum sensing in Vibrio harveyi. Bioluminescence experiments with signal molecule receptor double mutants revealed that the furanone blocks all three channels of the $V$. harveyi quorum sensing system. In further experiments using mutants with mutations in the quorum sensing signal transduction pathway, the compound was found to block quorum sensing-regulated bioluminescence by interacting with a component located downstream of the Hfq protein. Furthermore, reverse transcriptase real-time polymerase chain reaction with specific primers showed that there was no effect of the furanone on luxR $R_{V h}$ mRNA levels in wild-type $V$. harveyi cells. In contrast, mobility shift assays showed that in the presence of the furanone, significantly lower

Received 11 May, 2007: accepled 15 May, 2007. "For correspnnonee. E-mail Wily Verslraete $Q$ UGent.be: Tel. (+32) 9 2645976 : Fax (+32) 92646248.

\begin{abstract}
levels of the $\operatorname{Lux}_{v \mathrm{v}}$ response regulator protein were able to bind to its target promoter sequences in wildtype $V$. harveyi. Finally, tests with purified LuxPvh protein also showed less shifts with furanone-treated LuxR $_{\mathrm{vh}}$, whereas the LuxR $\mathrm{R}_{\mathrm{V} h}$ concentration was found not to be altered by the furanone (as determined by SDS-PAGE). Therefore, our data indicate that the furanone blocks quorum sensing in $V$. harveyi by rendering the quorum sensing master regulator protein LuxPh $_{v h}$ unable to bind to the promater sequences of quorum sensing-regulated genes.
\end{abstract}

\section{Introduction}

Vibrio harveyi is a Gram-negative, luminescent marine bacterium that can be found free-living in the water co'umn as well as in association with marine animals (Thompson et al., 2004). With the rapid deveiopment of the aquaculture industry, the species is becoming increasingly recognized as an important pathogen of marine vertebrates and invertebrates (Austin and Zhang, 2006). Because of the development and spread of antibiotic resistance in these bacteria, antibiotic treatments are becoming inefficient (Karunasagar et al, 1994; Moriarty, 1998) and theretore, alternative conirol strategies are being developed. One of these strategies is the disruption of bacterial cell-to-cell communication, called quorum sensing (Defoirdt et al, 2004).

Unlike many other Gram-negative bacteria, $V$. harveyi has been reported to use a multichannel quorum sensing system (Fig. 1). The first channel of this system is mediated by the Harveyi Autoinducer 1 (HAl-1), an acylated homoserine lactore (AHL) (Cao and Meighen, 1989). The second channel is mediated by the so-called Autoinducer $2(A \mid-2)$, which is a furanosyl borate diester (Chen et al., 2002). The chemical structure of the third autoinducer, called Cholerae Autoinducer 1 (CAI-1) is still unknown (Henke and Bassier, 2004a). All three autoinducers are detected at the cell surface and activate or inactivate target gene expression by a phosphorylation/ dephosphoryiation signal transduction cascade. Phenotypes that were found to be controllec by this quorum 

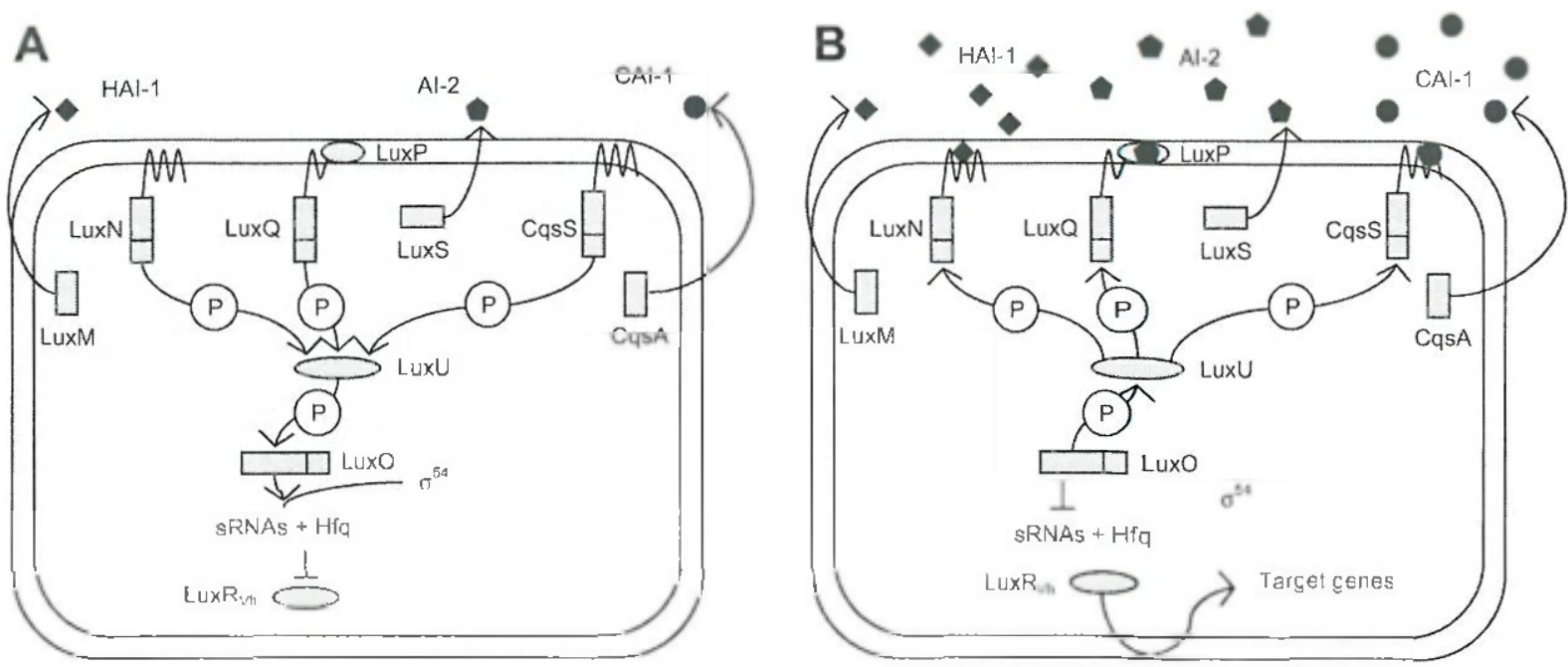

Fig. 1. Quorum sensing in Vibrio harveyi. The LuxM, LuxS and CqsA enzymes synthesize the autoinducers HAl-1. Al-2 and CAl-1 respectively. These autoinducers are detected at the cell surface by the LuXN, LuxP-LuXQ and CqsS receptor proteins respeclively. A. At low signal molecule concentration, the receplors autophosphorylate and transfer phosphate to LuxO via LuxU. Phosphorylation activales LuxO, which together with $\sigma^{54}$ activates the produclion of small regulatory RNAs (SPNAs). These sRNAs, Iogether with the chaperone Hiq, destabilize the mRNA encoding the response regulator LuxR: n. Therelore, in the absence of auloinducers, the LuxPvh prolein is not produced. B. In the presence of high concentrations of the autoinducers, the receptor proteins swilch from kinases to phosphatases, which results in dephosphorylation ol LuxO. Dephosphorylated LuxO is inactive and therelore. the sANAs are not formed and the response regulator LuxRu is produced (adapled from Henke and Bassler, 2004a)

sensing system include bioluminescence (Bassler et al., 1993) and the production of several virulence factors such as a type III secretion system (Henke and Bassler, 2004b), extracellular toxin (Manefield et al., 2000) and a siderophore (Lilley and Bassler, 2000). Recently, we found that virulence of the bacterium towards the brine shrimp Artemia franciscana is also regulated by its quorum sensing system (Defoirdt et at. 2005)

One of the mechanisms to disrupt bacterial quorum sensing is the use of halogenated furanones, such as the natural furanone (5Z)-4-bromo-5-(bromomethylene)-3butyl-2(5H)-furanone. These furanones (natural occurring compounds as well as synthetic derivatives) were found to disrupt the expression of different AHL-regulated phenotypes in several Gram-negative species, without affecting their growth (Hentzer and Givskov, 2003; Rasmussen and Givskov, 2006). Because of the structural similarity between AHI. molecules and the furanones, it was originally hypothesized that these compounds disrupt AHLmediated quorum sensing in the Luxl/LuxRir-type of quorum sensing system by competitively binding to the AHL receptor site of the Vibrio fischeri LuxR $\mathrm{V}_{\mathrm{v}}$ protein (Givskov ef al., 1996). Later on, it was shown that the halogenated furanones promote rapid turnover of the LuxRvi-type AHL receptor protein, reducing the amount of LuXRVI available to interact with $\mathrm{AHL}$ and to act as transcriptional regulator (Manefield et al. 2002). More recently, Koch and colleagues (2005) used site-directed mutagenesis to study interactions between LuxR and halogenated furanones. The authors could not conclude that the furanones bind to the AHL-binding cavity and suggested that furanones do not compete in a classic way with the signal molecules.

Meanwhile, several research groups provided evidence that halogenated furanones also disrupt quorum sensingregulated gene expression in $V$. harveyi (Manefield et al, 2000: Ren et al., 2001: McDougald et al., 2003; Defoirdt ef al., 2006). However, because the quorum sensing system of $V$. harveyi is quite different from the $L u x] / L u x R_{v 1}$ type of quorum sensing system and does not contain a LuxR vil homalogue (Milton, 2006), the molecular mechanism of quorum sensing disruption in this species must be different from that in the Lux//LuxR vr $^{-t y p e}$ of system. Consequently, in this study, we aimed at defining the molecular mechanism by which the natural furanone (5Z)-4-bromo5-(bromomethylene)-3-butyl-2(5H)-furanone (Fig. 2) disrupts quorum sensing-regulated gene expression in this different type of quorum sensing system.<smiles>CCCCC1=C(Br)/C(=C/Br)OC1=O</smiles>

Fig. 2. Structure of the nalural furanone used in this study. 


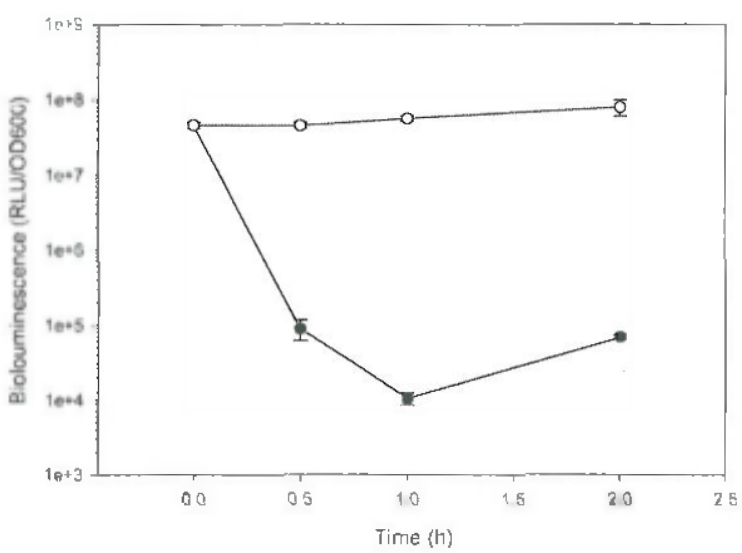

Fig. 3. Bioluminescence per unit cell density in wild-lype Vibrio harveyi $\mathrm{BB} 120$ as a Iunction of time, without (open symbols) and with (filled symbols) the nalural furanone (5Z)-4-bromo-5(bromomethylene)-3-butyl-2(5H)-furanone $\left(50 \mathrm{mg} \mathrm{l}^{-1}\right)$. The error hars represent the standard deviation of three replicales. Note that RLU is the relalive unit of fuminescence repcrted by the Lumac Biocounier M2500 lumincmeles.

\section{Results}

Impact of the furanone on quorum sensing-regulated bioluminescence of wild-type $\mathrm{V}$. harveyi

Bioluminescence is one of the phenotypes that is reguiated by the $V$. harveyi quorum sensing system and therefore, in a first experiment, the impact of the natural furanone (5Z)-4-bromo-5-(bromomethylene)-3butyl-2(5H)-furanone on the bioluminescence of wild-type $\checkmark$. harveyi was determined. Strain BB120 was grown in $\mathrm{LE}_{>0}$ medium to high cell density in order to activale quorum sensing-regulated bioluminescence, after which the furanone was added to the medium at $50 \mathrm{mgl}^{-1}$. The compound blocked bioluminescence of BB120, with over 3 log units difference between the furanone-treated and the untreated cultures already $0.5 \mathrm{~h}$ after the addition of the furanone (Fig. 3). Consistent with this, luciferase activity in protein lysates of furanone-treated BB120 cells was found to have decreased with approximately $1 \log$ unit $0.5 \mathrm{~h}$ after the addition of $50 \mathrm{mg} \mathrm{l}^{-1}$ furanone (Fig. 4). The bacterial alkaline phosphatase activities of the protein lysates were also measured in order to verify that the furanone had no effect on phenolypes that are not regulated by the quorum sersing system. As expected, there was no significant difference in bacterial alkaline phosphatase activities between furanone-treated and untreated cells (Fig. 4).

Impact of the furanone on bioluminescence of $\mathrm{V}$. harveyi autoinducer receptor double mutants

The $V$. harveyi quorum sensing system consists of three channels, with each channel being activated by a different type of signal molecule (Fig. 1). In order to determine the impact of the furarione on the different channe:s, the signal molecule receptor double mutants JAF375 (sensor $\mathrm{HAl-1}{ }^{-}$, sensor $\mathrm{Al}-2^{-}$: sensor $\mathrm{CAl}-1^{+}$), JMH597 (sensor $\mathrm{HAl}-1$, sensor Al-2+, sensor $\mathrm{CAl}-1^{-}$) and $\mathrm{JMH} 612$ (sensor $\mathrm{HAl}-1^{+}$, sensor $\mathrm{Al}_{-2}^{-2}$, sensor $\mathrm{CAl}_{-1} 1^{-}$) were used. Because of the mutated receptors, bioluminescence in these mutants is only responsive to one of the three sigral molecules (Henke and Bassler. 2004a). The mutants were grown to high cell densities, and after furanone addition: bioluminescence was found to be blocked in all three double mutants in a concentration-dependent way similar to the one obtained for the wild type (Fig. 5). This indicates that all three channels of the quorum sensing system were blocked.

Impact of the furanone on bioluminescence of constitutively luminescent $\mathrm{V}$. harveyi mutants with mutations in the quorum sensing signal transduction cascade

Because the three signal mclecules have quite different chemical structures (Henke and Bassler, 2004a), we suspected that the furanone did not block quorum sensingregulated bioluminescence by competing with the autoinducers for receptor sites but rather by interfering with the quorum sensing signal transduction. In order to test this hypothesis, the effects of the furanone on bioluminescence of mutants that were fixed in the high cell-density contiguration at different stages in the quorum sensing signal transduction cascade were investigated. The mutants JAF553 and JAF483 contain a point mutation in the IUXU and luxO genes, respectively. that render the LuxU ard LuxO proteins incapable of phosphorelay (Freerran and

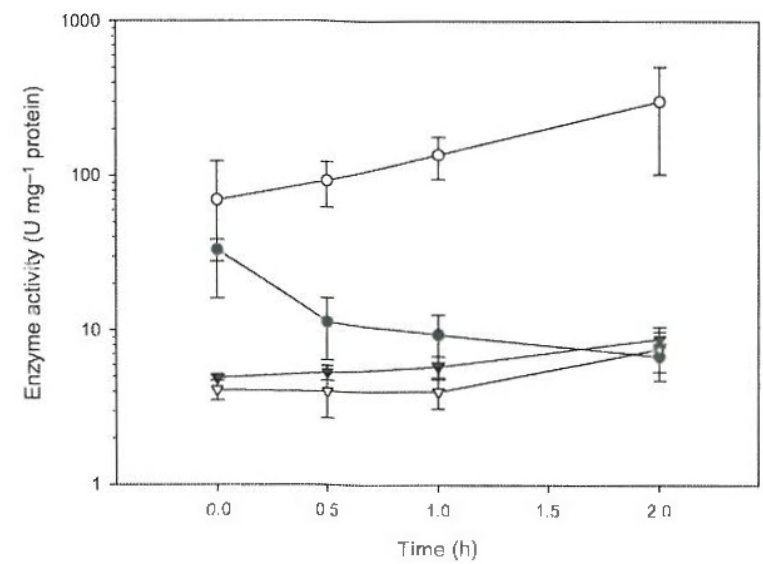

Fig. 4. Lucilerase (circles) and bacterial alkaline phcsphatase (triangles) activilies in prolein lysates ol wild-fype Vibrio harveyt Be120 as a funclion of lime, withoul (open symbols) and with (filled symbols) the nalural luranone (5Z)-4-bromo-5-(bromomelhylene)3-bulyl-2(5h)-luranone $\left(\left.50 \mathrm{mg}\right|^{-1}\right)$. The error bars represenl lhe standard devialion of four independenl experiments. 


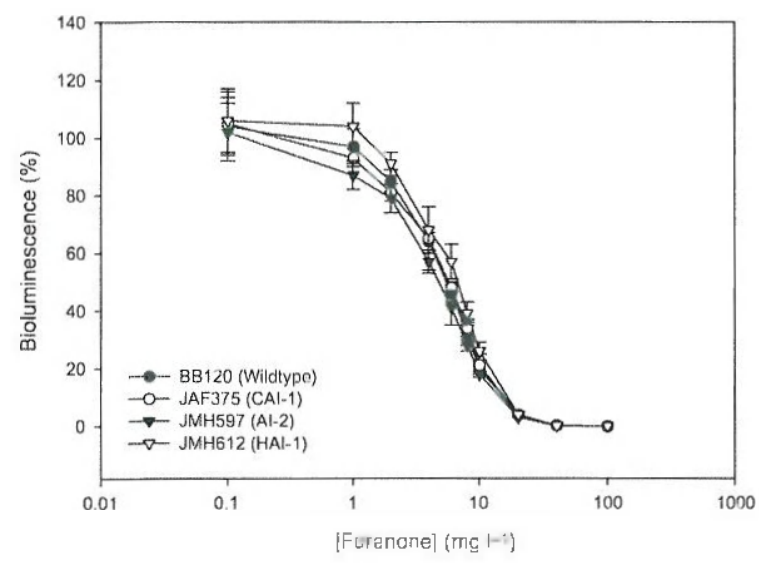

Fig. 5. Bioluminescence of the Vibrio harveyi wild type (BB120) and the double mutants JAF375 (sensor HAl-1" ${ }^{-}$, sensor Al-2sensor CAl-1-1), JMH597 (sensor HAl-1", sensor Al-2', sensor CAl-1-) and JMH612 (sensor HAl-1 ${ }^{+}$, sensor Al-2-, sensor CAl-1-) as a function of the concentration of the natural furanone (5Z)-4-cromo-5-\{́loromemethyene'-3-'cutyi-2(5H)-furanone. Luminescence measuremenis were pertormed $0.5 \mathrm{~h}$ after the addition of the furanone. For each strain, the bioluminescence without the addition of furanone was set at $100^{\circ}$, and the other samples were normalized accordingly. The error bars represent the standard deviation of three replicates.

Bassler, 1999a.b). Strain BNL258 has a Tn5 insertion in the htq gene, resulting in a non-functicnal Hfq protein (Lenz et al., 2004). Hence, because of the nature of these mutations, the three mutants are constitutively luminescent and therefore, blocking luminescence in one of them would indisate that the furanone acts downstream of the mutated component. The furanone, at $50 \mathrm{mg} \mathrm{l}^{-1}$, biocked tuminescence in all three mutants (Fig. 6). In wild-type $V$. harveyi, the Hfq protein acts together with small regulatory ANAs to destabilize the mRNA of the master regulator LuxRvh (see Fig. 1). In the mutant BNL258, a transposon insertion has rendered the Hfq protein non-functional and therefore, in this mutant, the luX $R_{v k}$ mANA cannot te destabilized by the quorum sensing signal transduction system, resulting in a constitutively expressed bioluminescence (Lenz et al., 2004). The fact that the furanone blocked bioluminescence in this mutant indicates that it acts downstream of $\mathrm{Hfq}$, i.e. at the level of the IuxR MnRA and/or the LuxRvn protein.

\section{Impact of the furanone on luxR $m$ mANA levels}

In order to verify whether the furanone indeed affects the quorum sensing master regulator, an experiment was set up in which the impact of the addition of the compound on luxR R mRNA was studied. Wild-type $V$. harveyi BB120 was grown to high cel! density, after which the natural furanone was added at $50 \mathrm{mg} \mathrm{l}^{-1}$. The addition of the furanone resulted in a rapid decrease in luminescence (Fig. 3). IuxRvh mRNA levels were quantified relatively by reverse transcriptase real-time polymerase chain reaction (PCR) with specific primers and the RNA polymerase A subunit (rpoA) mRNA was analysed as a control of a non-quorum sensing-regulated gene. For both genes, the mRNA levels followed a similar irend, with no significant difference between furanone-treated and untreated cells (Fig. 7). From these results. we conclude that the furanone has no effect on $1 u x R_{v_{1}}$ mRNA levels.

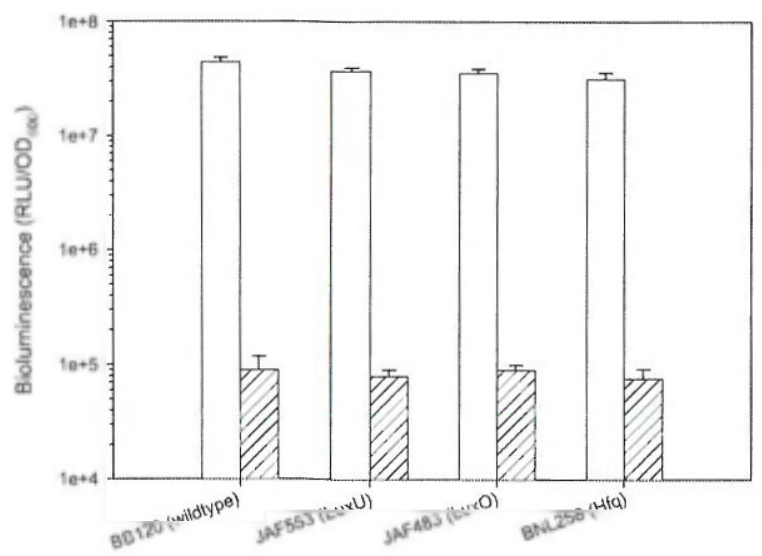

Fig. 6. Bioluminescence ct wild-1ype Vibrio harveyi BB120 and the mLtanls JAF553 (hxU H58A), JAF483 (hixO D47A) ano PNL258 (hig:: Tn5lacZ) withoul (white bars) and wilh (striped bars) the natural luranone (5Z)-4-bromo-5-(bromomethylene)-3-butyi-2(5H)furanone $\left(\left.50 \mathrm{mg} \mathrm{l}\right|^{-4}\right)$. Measuremenls were performed $0.5 \mathrm{~h}$ after the addition of the furanone. The error bars represent the slandard deviation of three replicates. Note that RLU is the relative unit of luminescence reported by the Lumac Riocounter M2500 iumincmeter.

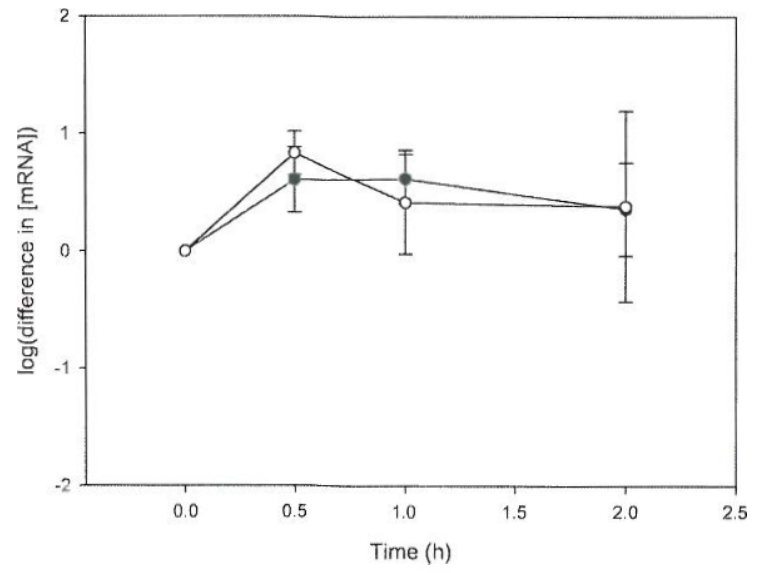

Fig. 7. Difference in $/ u x R_{i x}$ (filled symbols) and rpoA (open symbols) mANA kevels between witc'-lype Vibrio harveyi $\mathrm{BB} 120$ cells treated with the natural turanone (5Z)-4-bromo-5(bromomethylene)-3-butyl-2(5H)-1tranone $\left(50 \mathrm{mg} \mathrm{l}^{-1}\right)$ and unlreateo cells, as determined by reverse transcriptase real-lime PCF with specific primers. The error bars represenl the standard devialion of two independent experiments. 
A

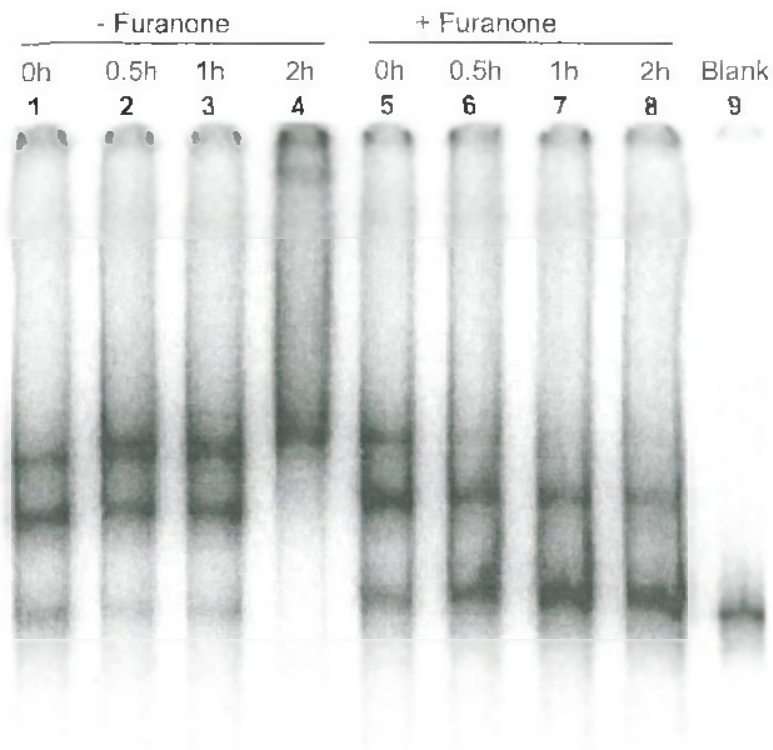

B

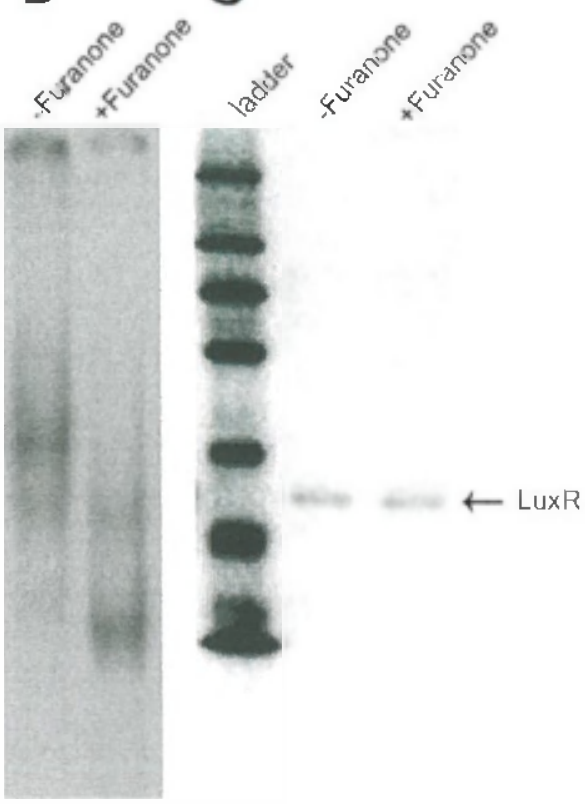

Fig. 8. Luxf ${ }_{v h}$ DNA binding as determined by mobility shifts.

A. Autoradiograph after $5 \%$ polyacrylamide gel electrophoresis of $5^{\prime}{ }^{\prime}$ P-labelled $h x R_{t h}$ promnler DNA containing the LuxR binding sites, mixed wilh $0.5 \mathrm{\mu g}$ of protein lysates from wild-type Vibrio harveyi BB120: lanes 1-4, addition of lysales taken at different time points from an untreated culture; lanes 5-8, addition of lysates taken at different time points from a cullure trealed with 50 mg $\left.\right|^{-1}$ of the natural Iuranone (5Z)-4-bromo-5-(bromomelhylene)-3-butyl-2(5/H)-furanone; last lane, blank (addition of lysate from the luxR-negalive slrain MA1130).

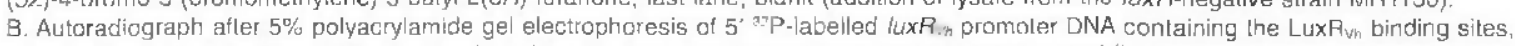
mixed with purified LuxAvn, which was incubated in vitro for $1 \mathrm{~h}$ with or without the furanone $\left(50 \mathrm{mg}^{-1}\right)$.

C. SDS-PAGE ct the same samples as in panel B

Impact of the furanone on $L u x R_{v h}$ protein levels and $L_{u x R_{v h}}$ binding to its target promoter sequences

Mobility shifts using radiolabelled lux $F_{V h}$ promoter DNA containing the LuxR $v_{v h}$ binding sites showed less shifts with cell lysates from furanone-treated cells when compared with unireated cells (Fig. BA), indicating that there were sigrificaritly lower levels of the protein able to bind the promoter DNA. In order to quantify the difference in bound LuxRyn levels between furanone-treated and untreated cells, a titration for mobility shitts of luxR $R_{v n}$ promoter DNA using the 2-h samples was performed. This titration revealed that $0.025 \mu \mathrm{g}$ iysate of untreated cells gave the same shift as $0.5 \mu \mathrm{g}$ lysate of furanone-treated cells (data not shown), which indicates that there was a

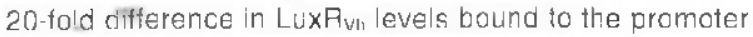
DNA. The luxCDABEGH promoter DNA was also used to check for LuxF $\mathrm{V}_{V 1}$ shifts, with similar findings (Fig. 9). These observations could be explained by the furanone either decreasing translation or increasing turnover of LuxR $_{v l}$, or altering the protein in such a way that it is rendered unable to bind to its target promoter. Some additicnal tests were performed to dear this up. First. $50 \mathrm{mgl}^{-1}$ chloramphenico! was added to $V$ harveyi
BB120 cultures in order to stop translation of LuxPln. In these cultures, there was no effect on LuxPivn mobility shifts in the absence of furanone throughout the $1 \mathrm{~h}$ of incubation, whereas in the presence of furanone, again less shifts occurred (data not shown). This suggests that LuxRvin has quite a slow turnover and that the furanone acts on pre-existing LuxRyn. Firally, the furanone was added to puritied LuxF ${ }_{V h}$, and after subsequent incubation of the mixture, again sigrificantly lower levels of LuXPVh were found to bind to the promoter DNA when compared with untreated LuxR $\mathrm{VII}_{1}$ (Fig. 8B). Interestingly, SDS-PAGE showed that the concentration of LuXP(vh in the mixtures was not affected by the furanone (Fig. $8 \mathrm{C}$ ). Together, these data lead to the conclusion that the furanone compound renders LuxFvh unable to bind to its target promoter sequences, without degrading the protein.

\section{Discussion}

Disease caused by antibiotic resistant lumimescent vibrios is a serious problem in the aquaculture industry (Austin and Zhang, 2CO6). Recent investigalions have pointed out 


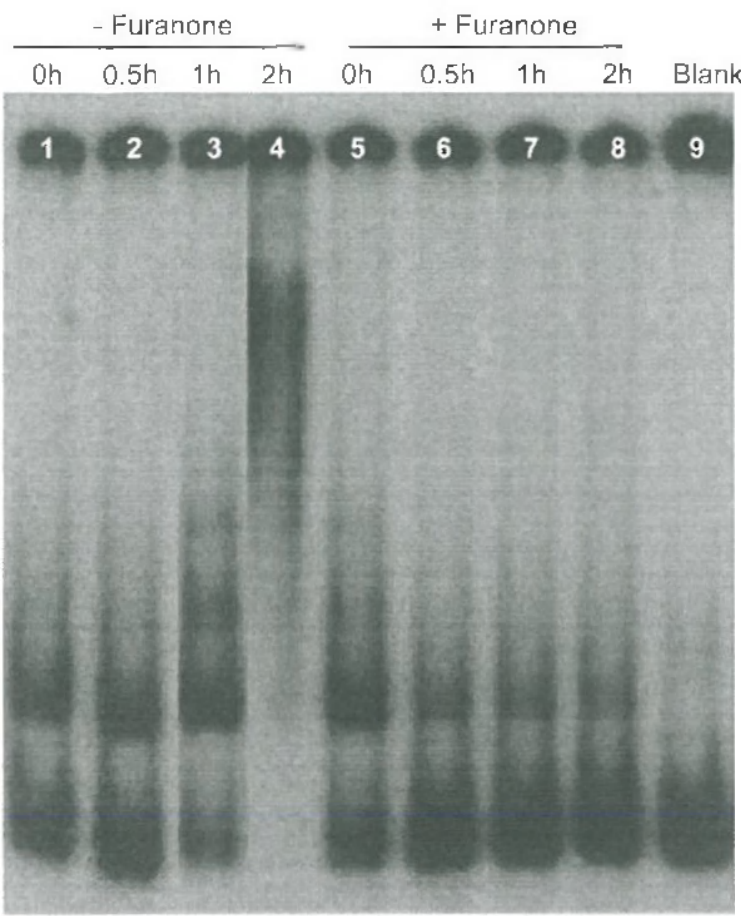

Fig. 9. LuxR DNA binding as determined by mobility shilts. Autoradiograph alter $5 \%$ polyacrylamide gel electrophoresis of 5 "P-labelled luxCDAAEGH promoter DNA containing the LuxRyh binding sites, mixed with $0.5 \mathrm{~kg}$ of prolein lysales from wild-type Vibrio harveyi $\mathrm{BB} 120$ : lanes 1-4, addition of lysates laken al different time points irom an untreated cullure; lanes $5-8$. acdilion ol iysales taken at dillerenl time points from a culture treateo wilh $\left.50 \mathrm{mg} \mathrm{|}\right|^{-1}$ of the natural luranone (5Z)-4-bromo-5-(bromomeihylene)3-butyl-2(5H)-furanone; lasil lane, blank (addilion of lysate from the luxR-negative strain MA1130).

that disruption of the quorum sensing system of these bacteria by using halogenated furanones could be a promising alternative biocontrol strategy (Manefield et al., 2000; Defoirdt ef al. 2006). In view of the potential practical applications of this type of compounds, it is of significant interest to define the mode of action of the furanones in these bacteria. Hence, in this study, we aimed at elucidating the molecular mechanism of quorum sensing disruption by the ratural furanone (5Z)-4-bromo-5(bromomethylene)-3-butyl-2(5H)-furanone in $\mathrm{V}$. harveyi.

In a first series of experiments, the impact of the naturat furanone (5Z)-4-bromo-5-(bromomethylene)-3-butyl2(5H)-furanone on quorum sensing-regulated bioluminescence of $V$. harveyi wild type and quorum sensing mutants was determined. Importantly, halogenated furanones were shown betore not to block bioluminescence when expressed from an external promoter (Givskov et al., 1996), indicating that the biochemical function of the Lux proteins is not affected. Consistent with the work of Manefield and colleagues (2000): the compound was found to block bioluminescence in wild-type $V$. harveyi BB120 in a concentration-dependent way. Moreover, luciferase activity was significantly decreased in protein lysates of furanone-treateo BB120 cells. In order to determine the effect of the furanone on the three different channels of the $V$. harveyiquorum sensing system, its impact on bioluminescence of the signal molecule receptor double mutants JAF375, JMH597 and JMH612 (Henke and Bassler, 2004a) was studied. The compound was shown to block bioluminescence in all three double mutants in a pattern similar to the one obtained for the wild type. Because of the mutated receptors, bioluminescence in these mutants is only responsive to one of the three signal molecules, which implies that all three channels of the quorum sensing system were blocked. These data confirm the reports by Ren and colleagues (2001) and McDougald and colleagues (2003), who determined the impact of the furanone on the Al-2- and/or HAl-1mediated channels of the system by using the $\mathrm{Al}-2$ and/or HAl-1 receptor mutants $\mathrm{BB} 886$ and $\mathrm{BB} 170$ (which thus were still responsive to both $\mathrm{HAl}-1$ and $\mathrm{CAl}-1$ and $\mathrm{Al}-2$ and CAl-1 respectively). Noreover, cur results indicate that the furanone alsc blocks the CAl-1-mediated channel of the $V$. haveyi quorum sensing system.

Previously, the hypothesis that prevailed in literature was that the furanones disrupt quorum sensing in $\checkmark$. harveyi by displacing the signal molecules from their receptors (Manefield et al., 2000; Ren et al., 2001). However, because the three signal molecules have quite different chemical structures (aithough the exact structure of CAl-1 is still unknown; Henke and Bassler, 2004a), we suspected that the furanone did not block quorum sensing-regulated bioluminescence by competing with the autoinducers for receptor sites but rather by interfering with the quorum sensing signal transduction. In order to test this hypothesis, the effects of the furanone on bioluminescence of mutants that were fixed in the high celldensity configuration at different stages in the quorum sensing signal transduction cascade were investigated (i.e. LuxU, LuxO and $\mathrm{Hfq}$ ). We found that the furanone blocked bioluminescence in the hta mutant BNL258. Htq is a chaperone protein that acts together with small regulatory RNAs to destabilize the mRNA of the master regulator LuxR $\mathrm{R}_{v h}$. The Hiq protein is non-functional in strain BNL258, resulting in constilutively expressed bioluminescence (Lenz et al. 2004). The fact that the furanone blocked bicluminescence in this mutant indicates that it acts downstream of $\mathrm{Hfq}$, i.e. at the level of the luxR $R_{v h}$ mRNA and/or the LuXRVI, protein and not by displacing the signal molecules from their receptors.

The quorum sensing master regulator protein LuxRvh has been shown before to be a transcriptional activator that is required for expression of the lux operon (Swartzman et al, 1992; Swartzman and Meighen, 1993). 
Consequently, in a final series of experiments, the effect of the furanone on this response regulator protein was investigated. Reverse transcriptase real-time PCR with primers specific for $V$. harveyi luxhin revealed that the furanone has no effect on the concentration of the luxR $R_{V h}$ mRNA. In contrast, mobility shift assays showed that the concentration of the LuxRyh response regulator protein able to bind to its target promoter sequences significantly decreased after furanone addition, both in intact celis and in purified LuxRve extracts. Interestingly, the concentration of the LuxRyh protein was shown not to be affected by the furanone (as determined by SDS-PAGE analysis). LuxR is a member of the TetR family of transcriptional regulators containing a helix-turn-helix DNA binding domain (Ramos et al., 2005). Members of the TetR tamily that have been studied in depth, have been shown to bind DNA as dimers, but this has not yet been proven for LuxRyh. Because halogenated furanones are known to be very reacflve ccmpounds (Hentzer and Givskov, 20033) we hypothesize that the furanone reacts with the Lux $R_{v}$ protein, thereby altering it in such a way that it cannot bind the DNA anymore, either by changing the structure of the DNA binding domain or the regions involved in dimer formation (that is, if $\mathrm{Lu} \times \mathrm{R}_{\mathrm{V}}$ also needs to dimerize in order to bind DNA). However, the elucidation of the exact biochemical reaction mechanism between halogenated furanones and LuxR $\mathrm{V}_{\mathrm{V}}$ (with the aid of mass spectrometry) will be part of future work at our laboratories

The fact that the furanone affects the master regulator rather than selectively bincking one of the channeis of the $V$. harveyi quorum sensing system is quite important with respect to possibie practical applications because there seems to be a difference in the relative importance of the three channels for a successful infection of different hosts. Indeed, disrupting only the Al-2-mediated channel of the $V$. harveyi quorum sensing system has been shown to significantly increase survival of the brine shrimp $A$. franciscana, whereas the HAl-1-mediated channel had no effect on infection of the shrimp (Defoirdt et al, 2005). In contrast. both the HAl-1- and Al-2mediated channel neevied to be disrupted in orcier to decrease mortality of grotobiotic rotifers (Brachionus plicatilis) caused by $V$. harveyi (Tinh et al., 2007). Because the furanone blocks all three channels of the system at once by acting at the end of the quorum sensing signa transduction cascade, it will not be necessary to develop different furanone compounds to protect different hosts Consistent with this, the natural furanone was shown to protect both brine shrimp and rotifers from luminescent vibrios (Defairdt ef al, 2006; Tinh et al. 2007), In addifion to this, several human pathogens, inciuding Vibrio cholerae, Vibrio parahaemolyticus and Vibrio vulnificus have been found to contain a LuxR ho homologue (Jobling and Holmes, 1997; McCarter, 1998; McDougald ef al, 2000). Moreover, the LuxAvn homologues have been shown before to regulate virulence factor production in these species as well (Henke and Bassler, 2004b Milton, 2006) and consequently, the furanones might be useful to control infections caused by these human pathogens.

In addition to affecting both $V$. fischeri LuxPvy (Manefield et al., 2002) and $V$ harveyi Luxfin (this study), covalent binding of this natural furanone to the Escheri chia coli LuxS protein has been reported (Ren ef al. 2004). Hence, it can be hypothesized that these fura nones react with certain reactive groups which are present in different regulatory proteins. It therefore seems that the macro-alga Delisea pulchra has evolved a sophisticated quorum sensing disruption-based defence system, producing compounds that affect different types of signal regulators in a non-growth inhibitory way. In view of the broad range of bacteria that can potentially colonize marine organisms. the production of brcad spectrum quorum sensing-disrupting compounds by the alga probably conters a strong evolutionary advantage.

In conclusion, the results presented in this article show that the natural furanone (5Z)-4-bromo-5(bromomethylene)-3-butyl-2(5H)-furanone disrupts quorum sensing-regulated gene expression in $V$. harveyi by decreasing the DNA-binding activity of the quorum sensing master regulator protein LuxR $\mathrm{V}_{\mathrm{V}}$. These results are of significant practical interest because they suggest that the furanone could be used as a broad spectrum biocontrol agent to protect a variety of hosts trom different pathogenic vibrios in which virulence factor production is regulated by a LuxRivn homologue

\section{Experimental procedures}

\section{Furanone preparation}

The natural furanone (5Z)-4-bromo-5-(bromomethylene)-3butyl-2(5H)-furanone was synthesized as described previously (Ren et al., 2001). The furanore was dissolved and diluted in pure ethanol and stored at $-20^{\circ} \mathrm{C}$.

\section{Bacterial strains and growth conditions}

The strains that were used in this study are shown in Table 1. All strains were grown in Luria-Bertani medium containing $20 \mathrm{gl}^{-1} \mathrm{NaCl}\left(\mathrm{LB}_{20}\right)$ at $2 \mathrm{~B}^{\circ} \mathrm{C}$ under constant agitation. Spectrophotometry at $\mathrm{OD}_{600}$ was used to measure growth. Luminescence was measured with a Lumac Biocounter M2500 luminometer (Lumac b.v., Landgraaf, the Netherlands).

For all experiments, $V$, harveyi strains were grown to an $\mathrm{OD}_{600}$ of approximately 0.75 , after which the furancne was added to the cultures in the appropriate concentration and the cultures were further incubated at $28^{\circ} \mathrm{C}$ with shaking. Unless otherwise indicated, samples were taken in triplicate $0.5 \mathrm{~h}$ after furamone addition. 
Table 1. Slrains used in this study.

\begin{tabular}{|c|c|c|}
\hline Strain & Phenolype & Reterence \\
\hline Vibrio harveyi $\mathrm{BB} 120$ & $\begin{array}{l}\text { Wild type from which strains BNL258, JAF375, JAF483, } \\
\text { JAF553, JMH597 and JMH612 are derived }\end{array}$ & Bassler ef al. (1997) \\
\hline Vibrio harveyi BNL258 & hfq:Tл5lacZ & l.enz et al. (2004) \\
\hline Vibrio harveyi JAF375 & $h \times N: \mathrm{Cm}^{A} \operatorname{lu} \times Q: \mathrm{Kan}^{\mathrm{P}}$ & Freeman and Bassler (1999a) \\
\hline Vibrio harveyi JAF 483 & IuxO D47A linked to $\mathrm{Kan}^{\mathrm{F}}$ & Freeman and Bassler (1999a) \\
\hline Vihrio harveyi JAF553 & luxU H58A linked to Kan ${ }^{A}$ & Freeman and Bassler (1999b) \\
\hline Vibrio harveyi JMH597 & LuN::Tn5 cgsS:: $\mathrm{Cm}^{\mathrm{F}}$ & Henke and Bassler (2004a) \\
\hline Vibrio harveyi JMH61? & HXPQ::Tn5 cqsS: $\mathrm{Cm}^{R}$ & Henke and Bassier (2004a) \\
\hline Vibrio harveyi MA1130 & Isogenic LuxR mutant & Martin ef al, (1989) \\
\hline
\end{tabular}

\section{Protein assays}

Wild-type $V$. harveyi BB120 was used in the luciferase and bacterial alkaline phosphatase assays. Immediately before and 0.5. 1 and $2 \mathrm{~h}$ after the addition of the furanone. 2 units $\left[O D_{\text {fin }} \times\right.$ vol $\left.(\mathrm{mll})\right]$ were pelieted, sonicated in $0.5 \mathrm{ml}$ of $0.25 \mathrm{M}$ Tris, $\mathrm{pH} 8$ and the cellular debris removed (as described by Miyamoto et al., 1990). A modified Lowry assay was used to delermine the protein content (Markwell et al., 1981). In vitro luciferase and bacterial alkaline phosphatase activities were deterrined as described by Gursalus-Miguel and colleagues (1972) and Garen and Levinthal (1960).

\section{Primer design}

Specific primers for the amplification of $l u x R_{w h}$ and RNA polymerase A subunit (rpoA) mANA were designed using the Primer Express 2.0 software (Applied Biosystems, Foster City, USA). The primers were designed based on the consensus of the sequences that have been deposited before in GenBank. The combinations of the two primer sequences were blasted against GenBank. The primer sequences are shown in Table 2

\section{RNA extraction and reverse transcriptase real-time PCA}

The effect of the furanone on $/ U x R_{L h}$ mRNA concentrations was studied in wild-type $V$. harveyi BB120. Immediately before and 0.5, 1 and $2 \mathrm{~h}$ after furanone addition. Iumines cence and cell density $\left(\mathrm{OD}_{600}\right)$ of the cultures were measured and $0.5 \mathrm{ml}$ of samples for RNA extraction were taken, which were immediately frozen in cold ethanol $\left(-80^{\circ} \mathrm{C}\right)$. RNA was isolated using the Oiagen RNeasy Mini Kit (Qiagen, Hilden, Germany) according to the manufacturer's instructions. RNA extracts were treated with RNAse-tree DNAse I (Fermentas, St. Leon-Rot, Germany), atter which the RNA quantity was checked spectrophotometrically. ANA concentrations obtained were all around $300 \mathrm{ng} \mu^{-1}$. RNA quality was confirmed by electrophoresis. CDNA was obtained by reverse

Table 2. Frimers used in this sluoy.

\begin{tabular}{|c|c|c|}
\hline Target & Primer & Sequence \\
\hline$r p O A$ & 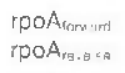 & $\begin{array}{l}\text { 5'-CGTAGCTGAAGGCAAAGATGA-3' } \\
\text { 5'-AAGCTGGAACATAACCACGA-3' }\end{array}$ \\
\hline$h x R_{\mathrm{y} \text { yn }}$ & 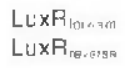 & $\begin{array}{l}\text { 5'-TCAATTGCAAAGAGACCTCG-3' } \\
\text { 5'-AGCAAACACTTCAAGAGCGA-3' }\end{array}$ \\
\hline
\end{tabular}

transcription using the Qiagen One Step RT-PCA kit (Qiagen), according to the manufacturer's instructions.

Real-time PCR was performed with the specific lux $R_{v h}$ and rpoA primers. Amplicon lengths are 84 bp and 197 bp for lux $R_{V h}$ and rpoA respectively. Amplification was perlormed in $25 \mu$ reaction mixtures using the SYBR Green PCA Master Mix kit (Applied Biosystems, Nieuwerkerk a/d ljssel, the Netherlands), according to the manufacturer's instructions, in optical 96-well reaction plates with optical caps (Applied Biosystems). The thermal profile was as follows: $50^{\circ} \mathrm{C}$ for $2 \mathrm{~min}$ and $95^{\circ} \mathrm{C}$ for $10 \mathrm{~min}$ followed by 40 cycles of $95^{\circ} \mathrm{C}$ for $30 \mathrm{~s}, 54^{\circ} \mathrm{C}$ tor $1 \mathrm{~min}$, and $60^{\circ} \mathrm{C}$ for $1 \mathrm{~min}$. Amplicon dissociation curves were determined by constant fluorescent measurement during a final heating step at $60^{\circ} \mathrm{C}$ to $95^{\circ} \mathrm{C}$ at $0.1^{\circ} \mathrm{C}$ $\mathrm{s}^{-1}$ ramping speed. The melting temperatures for the amplicons were $77^{\circ} \mathrm{C}$ and $82^{\circ} \mathrm{C}$ for lux $\beta_{V_{h}}$ and rpo $A$ respectively. The template DNA in the reaction rixtures was amplified and monitored with an AEI Prism SDS 7000 instrument (Applied Biosystems). The difference in mRNA levels between furanone-treated and untreated extracts was calculated as follows:

$\log$ (difference in concentration $)=\Delta \mathrm{C}$ / $/$ regression coefficient

with $\Delta C_{1}$ the difference in $C_{1}$ value between furanone-treated and untreated extracts. The regression coefficients between $\log$ (concentration) and $C_{1}$ value were determined by analysing a 10-fold dilution series of a $V$. harveyi BB120 DNA extract and were $-3.380\left(A^{2}=0.998\right)$ and $-3.597\left(A^{2}=0.993\right)$ for luxFva and rpoA respectively.

\section{Mobility shift assays}

The effect of the furanone on LuxR $\mathrm{vh}_{\mathrm{h}}$ protein concentrations was studied in wild-type $V$, harveyi BB120 $1 \mathrm{~mm}$ ediateiy before and $0.5,1$ and $2 \mathrm{~h}$ after the addition of the furanone, 2 units $\left[O D_{600} \times \mathrm{val}(\mathrm{ml})\right]$ were pelleted, sonicated in $0.5 \mathrm{ml}$ of $0.25 \mathrm{M}$ Tris, $\mathrm{pH} 8$ and the cellular debris removed (as described by Miyamoto et al., 1990). In the experiment that aimed at testing whether the furanone affected translation or acted on pre-existing translates, cultures were treated with $50 \mathrm{mg} \mathrm{l}^{-1}$ chloramphenicol Sigma-Aldrich (Bornem, Belgium) before furanone addition. Mobility shift assays were conducted as described previously (Swartzman and Meighen, 1993) using radiolabelled $/ 4 x \beta_{V h}$ promoter DNA (Chatterjee et al., 1996) or luxCDABEGH promoter DNA (Mivamoto el al. 1996) containing the LuxFun binding sites. The amount of retarded DNA was quantfied as described in Miyamoto and colleagues (1996) using a Fuji bioimage. 
Experiments with purified LuxR $R_{V h}$

LuxF $_{v h}$ purification was carried out as described previously (Swartzman and Meighen, 1993). The purified LuxR $\mathrm{wh}_{\mathrm{w}}$ was stored in $50 \mathrm{mM} \mathrm{NaPO}_{4}, 300 \mathrm{mM} \mathrm{NaCl}, \mathrm{pH}$ 8.0. The protein concentration (as determined by Bio-Rad protein assays) was $0.2 \mathrm{mg} \mathrm{m}^{-1}$. To glass tubes containing $40 \mu \mathrm{l}$ of the prctein preparation, $0.2 \mu \mathrm{l}$ ot absolute ethanot or $0.2 \mu \mathrm{l}$ of furanone (10 $\mathrm{mg} \mathrm{ml}^{-1}$ in ethanol) were directly added. The tubes were incubated in a $37^{\circ} \mathrm{C}$ water bath for $1 \mathrm{~h}$ and then stored at $4^{n} \mathrm{C}$. For mobility shift analyses, the samples were diluted 10-fold in storage buffer and $1 \mu \mathrm{l}(0.02 \mu \mathrm{g})$ was assayed. For SDS-PAGE, $1 \mu \mathrm{g}$ of protein was applied and $10 \%$ SDS-PAGE was performed according to Maniatis and colleagues (1982).

\section{Acknowledgements}

We thank Bonnie Bassler for generously providing us with the $V$. harveyi mutants. This work was supported by the 'Instituut voor de aarmoediging van Innovatie door Wetenschap en Technologie in Vlaanderen' (IWT Grant no. 3a205), the 'Fonds voor Wetenschappelijk Onderzoek' (project no. G0230.02N), the National Institutes of Health (EROC387201A1) and the Canadian Institutes of Heatth Research (MT7672).

\section{References}

Austin, B., and Zhang, X.-H. (2006) Vibrio harveyt: a significant pathogen of marine vertebrates and invertebrates. Lell Appl Microbiol 43: 119-124.

Bassler, B.L., Wright, M., Showalter, A.E., and Silverman, M.R. (1993) Intercellular signaling in Vibrio harveyisequence and function of genes regulating expression of luminescence. Mol Microbio/ 9: 773-786.

Bassler, B.L., Greenberg, E.P., and Stevens, A.M. (1997) Cross-species induction of luminescence in the quorumsensing bacterium Vibrio haveyi. I Bacteriol 179: 40434045.

Cao, J.G., and Meighen, E.A. (1989) Purification and structural identification of an autoinducer for the luminescence sysiem of Vibrio harveyi. I Biol Chem 264: 21670-21676.

Chalterjee, J., Niyamoto, C.M., and Meighen, E.A. (1996) Autoregulation of luxf: the Vibrio harveyi lux-operon activator functions as a repressor. Mol Microbiol 20: 415-425.

Chen, X., Schauder, S., Potier, N., Van Dorsselaer, A., Pelczer, 1., Bassler, B.L., and Hughson, F.M. (2002) Structural identification of a bacterial quorum-sensing signal containing boron. Nature 415: 545-549.

Detoirdt, T., Boon, N., Bossier, P., and Verstraete, W. (2004) Disruption of bacterial quorum sensing: an unexplored strategy to fight infections in aquaculture. Aquaculture 240: $69-88$.

Defoirdt, T., Bossier, P., Sorgeloos, P., and Verstraete, $W$. (2005) The impact of mutations in the quorum sensing systems of Aeromonas hydrophila, Vibrio anguillarum and Vibrio harveyi on their virulence towards gnotobictica!ly cultured Artemia tranciscana. Environ Microbiol 7: 12391247.
Detoirdt, T. Crab, R., Wood, T.K., Sorgeloos. P. Verstraete W. and Bossier, P. (2006) Quorum sensing disrupting brominated furanones protect the gnotobiotic brine shrimp Artemia franciscana from pathogenic Vibrio harveyi, Vibrio campbellii, and Vibrio parahaemolyticus isolates. Appl Environ Microbiol 72: 6419-6423.

Freeman. J.A., and Bassler, B.L. (1999a) A genelic analysis of the function of LuxO, a lwo-component respense regulator involved in quorum sensing in Vibrio harveyi. Mol Microbiol 31: 665-677.

Freeman, J.A., and Bassler, B.L. (1999b) Sequence and function of LuxU: a Iwo-component phosphorelay protein that regulates quorum sensing in Vibrio harveyi. J Bacterio! 181: 899-906.

Garen: A., and Levirthal, C. (1960) A tine-struciure genetic and chemical study of the enzyme alkaline phosphatase of E. coli. I. Purfication and characterization of alkaline phosphatases. Binchim Blophys Acta 38: 470-483.

Givskov, M., de Nys, B., Manefield, M., Gram, L., Maximilien, R., Eberl, L., et al. (1996) Eukaryotic interference with homoserine lactone-mediated prokaryotic signalling. J Bacteriol 178: 6618-6622.

Gunsalus-Miguel, A., Meighen, E.A., Nicoli, M.Z, Nealson, K.H., and Hastings, J.W. (1972) Purification and properties of bacterlal luciferases. J Biol Chem 247: 398-404.

Henke, J.M., and Bassler, B.L. (2004a) Three parallel quorum sensing systems regulate gene expression in Vibrio harveyi. J Racteriol 186: 6902-6914.

Henke, J.M. and Bassler. B.L. (2004b) Quorum sensing regulates tyce III secretion in Vibrio haneyi and Vibrio parahaemolyticus. I Bacteriol 186: 3794-3805.

Hentzer, M., and Givskov, M. (2003) Pharmacological inhibition of quorum sensing for the treatment of chronic bacterial infections. J Clin invest 112: 1300-1307.

Jobling, M.G., and Holmes, R.K. (1997) Characterization of hapR, a positive regulator of the Vibrio cholerae HA/protease gene hap. and its identification as a functional homologue of the Vibrio harveyi luxA gene. Mol Microbiol 26: 1023-1034

Karunasagar, I., Pai, R., Malahti, G.R., and Karunasagar, I. (1994) Mass montality of Penaeus monodon larvae due to antibiotic-resistant Vibrio harveyi infection. Aquaculture 128: 203-209.

Koch, B., Liljelors, T., Persson, T., Nielsen, J., Kjelleberg, S., and Givskov, M. (2005) The LuxR receptor: the sites of interaction with quorum-sensing signals and inhibitors. Microbiology 151: 3589--3602.

Lenz, D.H., Mok, K.C., Lilley, B.N., Kulkarni, R.V., Wingreen, N.S., and Bassler, B.L. (2004) The small RNA chaperone Hiq and multiple small RNAs control quorum sensing in Vibrio harveyi and Vibrio cholerae. Cell 118: 69-82.

Lilley, B.N., and Bassler, B.L. (2000) Fegulation of qucrum sensing in Vibrio harveyi by LuxO and 854 . Mol Microbiol 36: 940-954.

McCarter, L.L. (1998) OpaR, a homolog of Vibrio harveyi LuxA, controls opacity of Vibrio parahaemolyticus. J Bacteriol 180: 3166-3173.

McDougald, D., Rice, S.A., and Kjelleberg, S. (2000) The marine pathogen Vibrio vuinificus encodes a putative homologue of the Vibrio harveyi regulatory gene luxR: a genetic and phylogenetic comparison. Gene 248: 213-221. 
McDougald, D., Srinivasan, S., Hice, S.A., and Kjelleherg, S. (2003) Signal-medialed cross-lalk regulates stress adaptation in Vibrio species. Microbiology 149: 1923-1933.

Manefield, M., Harris, L., Rice, S.A., de Nys, R., and Kjelleberg, S. (2000) Inhibition of luminescence and virulence in the black tiger prawn (Penaeus monodon) pathogen Vibrio harveyi by intercellular signal antagonists. Appl Environ Microbiol 66: 2079-2084

Manefield, M., Rasmussen, T.B., Hentzer, M.. Andersen, J.B. Steinterg, P., Kjelleberg, S., and Givskov, S. (2002) Halogenated furanones inhlbit qucrum sensing through accelerated Luxf Iturnover. Microbiology 148: 11191127.

Maniatis. T., Fritsch, F.F., and Sambrook, J. (1982) Molecular Cloning: A Laboratory Manual. Cold Spring Harbor, NY, USA: Cold Spring Harbor Laboratory.

Markwell, M.A.K., Haas, S.M., Tolbert, N.E., and Bieber, L.L. (1981) Protein determination in membrane and lipoprotein samples: manual and automated procedures. Methods Enzymol 72: 296-303.

Martin, M.O., Showalter, R.E., and Silverman, N. (1989) Identification of a locus controlling expression of luminescence genes in Vibrio harveyi. J Bacterio/ 171: 2406-2414

Milton, D. L. (2C06) Quorum sensing in vibrios: complexity for diversification. Int J Med Microbiol 296: 61-71.

Miyamoto, C.M., Meighen, E.A., and Graham, A.F. (1990) Transcriptional regulation of lux genes transierred into Vibrio harveyi. J Bacteriol 172: 2046-2054.

Miyamoto, C.M., Chalterjee, d., Swartzman, E., Szittner, R., and Meighen, E.A. (1996) The role of the lux autoinducer in regulating luminescence in Vibrio harveyi, control of luxA expression. Mol Microbiol 19: 767-775.

Moriarty, D.J.W. (1998) Disease control in shrimp aquaculture with probiotic bacteria. In Microbial Biosystems: New
Frontiers. Froceedings of the Eighth International Symposium on Microbial Ecology. Bell. C.R., Brylinsky, M. and Johnson-Green, P. (eds). Halifax, NS, Canada: Allantic Canada Society for Microbial Ecology.

Pamos, J.L., Martínez-Bueno, M., Molina-Henares, A.J., Terán, W. Watanabe, K., Zhang, X., et al. (2005) The TetP family of transcriptional repressors. Microbiol Mol Biol Rev 69: 326-356.

Rasmussen, T.B.. and Givskcv. M. (2006) Quorum-sensing inhibitors as anti-pathogenic drugs. Int $J$ Med Microbiol 296: $149-161$.

Ren, D., Sims, J., and Wood. T.K. (2001) Inhibition of biofilm formation and swarming of Escherichia coli by (5Z)-4-bromo-5-\{bromamethylene)-3-butyl-2 (5H)-furanone. Environ Microbiol 3: 731-736

Ren, D., Bedzyk, L., Ye, R.W., Thomas, S.M., and Wood, T.K. (2004) Differential gene expression shows natural brominated furanones interiere with the autoinducer-2 bacterial signaling system of Escherichia coli. Biolechnol Bioeng 88: 630-642.

Swartzman, E. and Meighen, E.A. (1993) Purification and characterizaticn of a poly-(dA-dT) lux-specitic DNA binding protein from Vibrio harveyi and identification as LuxA. $\checkmark$ Biol Chem 268: 16706-16716.

Swartzman, E., Silverman, M., and Meighen, E.A. (1992) The luxR gene product of Vibrio harveyi is a transcriptional activator of the lux promoter. I Bacteriol 174: 7490-7493.

Thompson, F.L., lida, T., and Swings, J. (2004) Biodiversity of vibrios. Microbiol Mol Biol Rev 68: 403-431.

Tinh, N.T.N., Linh, N.D., Wood, T.K., Dierckens, K., Sorgeloos, P., and Bossier, P. (2007) Interference with the quorum sensing systems in a Vibrio harveyi strain alters the growth rate of gnctohiolically cultured rotifer Brachionus plicatilis. J Appl Microbiol (in press) 